\title{
Characterization of Crop Residue-Derived Biochars Produced by Field Scale Biomass Pyrolyzer
}

\author{
Won K. Jung* \\ Delta Research Center, University of Missouri-Columbia, PO Box 160, Portageville, MO 63873
}

\begin{abstract}
Application of biochar to soils is proposed as a significant, long-term, sink for atmospheric carbon dioxide in terrestrial ecosystems. In addition to reducing emissions and increasing the sequestration of carbon, production of biochar and its application to soils will contribute improve soil quality and crop productivity. Objectives were i) to evaluate biochar productivity from crop residues using a low-cost field scale mobile pyrolyzer and ii) to evaluate characteristics of feedstocks and biochars from locally collected crop residues. Pyrolysis experiments were performed in a reactor operated at $400-500^{\circ} \mathrm{C}$ for $3-4$ hours using biomass samples of post-harvest residues of com (Zea mays L.), cotton (Gossypium spp.), rice (Oryza sativa L.), sorghum (Sorghum bicolor L.) and wheat (Triticum aestivum L.). Feedstocks differed, but average conversion to biochar was $23 \%$. Carbon content of biomass feedstock and biochar samples were $445 \mathrm{~g} \mathrm{~kg}^{-1}$ and $597 \mathrm{~g} \mathrm{~kg}^{-1}$, respectively. Total carbon content of biochar samples was $34 \%$ higher than its feedstock samples. Significant increases were found in $\mathrm{P}, \mathrm{K}, \mathrm{Ca}, \mathrm{Mg}$, and micro-nutrients contents between feedstock and biochar samples. Biochar from com stems and rice hulls can sequester by $60 \%$ and $49 \%$ of the initial carbon input into biochar respectively when biochar is incorporated into the soils. Pyrolysis conversion of com and rice residues sequestered significant amounts of carbon as biochar which has further environmental and production benefits when applied to soils. Field experiment with crop residue biochar will be investigated the stability of biochars to show long-term carbon sequestration and environmental influences to the cropping systems.
\end{abstract}

Key words: Biochar, Pyrolysis, Carbon sequestration, Crop residue

\section{Introduction}

Judicious management of crop residue is important not only to sustain crop production but also to reduce carbon emissions from crop production systems. Burning of crop residue leads to emission of $\mathrm{CO}_{2}$ and other greenhouse gases (GHGs) (Zhang et al., 2008). Conversely, crop residue can be composted and recycled as a major nutrient source. And direct return of crop residue to the soil can reduce chemical fertilizer use through improving nutrient use efficiency (Malhi et al., 2006; Teasdale et al., 2008). Use of compost and manure also improves the soil organic carbon (SOC) pool and enhances crop yield. Carbon sequestration in soil is a technique for long-term storage of carbon and has been proposed to mitigate global warming (Baldock and Smernik, 2002; Lal, 2004). Carbon sequestration

\footnotetext{
Received : December 28. 2010 Accepted : February 22. 2011

*Corresponding author : Phone: +15733795431

E-mail: jungw@missouri.edu
}

can be taken a step further by pyrolysis, the burning of plant biomass in a limited $\mathrm{O}_{2}$ environment to form biochar (Baldock and Smernik, 2002; Lehmann, 2007a).

Biochar resists microbial decomposition in the soil for a much longer time than regular biomass (Lehmann, 2009) to provide environmental benefits. Large amounts of biochar carbon may be sequestered in the soil for hundreds to thousands of years, but few studies have quantified or estimated the carbon sequestration as a result of biochar application (McHenry, 2009). Biochar application into soils lowered greenhouse gas emission by $12-84 \%$ compared with its direct combustion for energy purposes (Hansen et al., 2008).

Studies also show crop yields can increase with application of biochar as a soil amendment (DeLuca et al., 2009). Biochar improves soil fertility due to its strong exchange capacity to retain nutrients for plant uptake. This capacity also acts as an environmental buffer in which the biochar retains large quantities of nutrients and pesticides to reduce their losses by infiltration into ground water and runoff into surface 
waters (Van Zwieten et al., 2010). Crop residue biochar can be produced by pyrolysis, a thermal decomposition process used widely for converting solid fossil fuels into liquid and gaseous hydrocarbons and a solid char residue. Coal pyrolysis has been widely studied (Howard, 1981; Liang et al., 2007; Teng et al., 1997), but few investigations of crop biomass pyrolysis have been reported. Biomass carbon from crop residues is composed of cellulose, hemicellulose and lignin (Demirba, 2001; Goldstein and Company, 1981; McKendry, 2002).

Biomass pyrolysis to biochar by thermal decomposition of organic matter results in the production of char, liquid and gaseous products (Demirba, 2001). The process can sequester up to $50 \%$ of the initial carbon input that can be returned to the soil (Lehmann et al., 2006). Pyrolysis of biomass was evaluated for recovering a bio-oil (Mohan et al., 2006; Oasmaa et al., 2009). Lignin decomposes over a wider temperature range compared to cellulose and hemicelluloses which rapidly degrade over narrower temperature ranges. Lignin gives higher yields of charcoal and tar from biomass (Alves et al., 2006).

Historically, evidence for soil benefits from highly reduced carbon compounds have been known since the discovery of a black colored soil in the Amazon basin of Brazil termed Terra Preta. The charcoal in these soils was added by native Amazonians to create arable farmland (Glaser et al., 2000; Lehmann et al., 2006). Terra Preta soils contain higher levels of $\mathrm{P}$ and $\mathrm{Ca}$ (Glaser, 2007). They also have high soil organic matter (SOM) content and cation exchange capacity (Cunha et al., 2009), which can contribute to improve soil fertility. Carbon enhanced SOM offers other direct values through improved water infiltration, water holding capacity, structural stability, cation exchange capacity and soil biological activity (Lehmann, 2007b).

Several laboratory scale pyrolysis studies have been reported. However there are few practical field-scale studies involving biomass composition, small-scale pyrolysis and evaluation of land application of biochar in a somewhat closed system. Such as system may be easily adaptable to local producers for their field scale application. Therefore, objectives of this research were i) to evaluate biochar productivity from crop residues using a low-cost mobile pyrolyzer and ii) to evaluate characteristics of feedstocks and biochars from locally grown crop residues. In subsequent studies field testing of the biochar will be conducted to evaluate the long- term carbon sequestration and soil fertilization.

\section{Methods and Materials}

A low-cost field scale biomass pyrolyzer was constructed at University of Missouri-Delta Research Center and consisted of a steel cylinder with an inside diameter of $0.65 \mathrm{~m}$, height of $1 \mathrm{~m}$ and capacity of $0.33 \mathrm{~m}^{3}$ (Figure 1). Air-flow inlet and exhaust pipes were installed on the bottom and top of the pyrolyzer cylinder through which air flow is controlled manually during pyrolysis. A fine-mesh screen was installed $15 \mathrm{~cm}$ above the bottom of the reactor cylinder. Temperature during the pyrolysis process was monitored with a thermometer probe in the middle of the reactor. Crop residues were added to occupy about 80 to $85 \%$ of reactor capacity. Charcoal lighter fluid, a volatile mixture of phenol distillates, was sprayed onto the biomass surface to accelerate ignition and to nurture uniform burning of crop residue. Soon after ignition, the steel lid was closed with bolts to provide an oxygen limited reaction. Temperature was maintained at $400-500^{\circ} \mathrm{C}$ for $3-4$ hours. When finished, the lid was removed and water was sprayed on the biochar to prevent burn down. Three separate batches of each feedstock (replications) were pyrolyzed, after which the biochar samples were air-dried.

Residue from corn (Zea mays L.), cotton (Gossypium spp.), rice (Oryza sativa L.), grain sorghum (Sorghum bicolor L.) and wheat (Triticum aestivum L.) were used as biomass samples. Samples were obtained during 2010 at the University of Missouri-Delta Research Center research farm near Portageville, MO. Corn, cotton, grain sorghum were grown with ground water irrigation and conventional management practices recommended by the University of Missouri. The Sharkey soils of the research farm are on flood plains and low terraces of the Mississippi River; MLRA 131A. They are classified as very-fine, smectitic, thermic Chromic Epiaquerts (Soil Survey Staff, 1997). Crop residue samples were obtained after grain or cotton harvest and consisted of the whole plant except roots and grain/or bolls. Crop residues were air dried, chopped and sieved manually to give a particle size of 0.4-10 $\mathrm{mm}$. Wheat straw was collected at the local farm after grain harvest in May 2010. Rice residue (i.e, hulls) was collected from local rice mill (i.e., Riceland food, Inc., New Madrid, MO), and used 
Table 1. Moisture content of feedstock and pyrolysis results from biomass samples. Standard deviations are in parentheses $(n=3)$.

\begin{tabular}{|c|c|c|c|c|c|}
\hline Biomass sample & $\begin{array}{l}\text { Moisture content of } \\
\text { feedstock }\end{array}$ & $\begin{array}{l}\text { Feedstock } \\
\text { input }\end{array}$ & $\begin{array}{c}\text { Biochar } \\
\text { output }\end{array}$ & $\begin{array}{l}\text { Ash content of } \\
\text { biochar }\end{array}$ & $\begin{array}{l}\text { Biochar } \\
\text { yield }\end{array}$ \\
\hline & ------- ％ ------- & \multicolumn{2}{|c|}{ 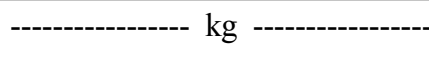 } & -------------------- & - \\
\hline Corn stems & $26.2(0.46)$ & $11.4(2.7)$ & $4.1(1.0)$ & $22.9(0.7)$ & $36.9(0.89)$ \\
\hline Cotton stems & $13.7(1.19)$ & 13.1 (1.6) & $2.2(0.5)$ & $13.6(2.0)$ & $17.0(0.32)$ \\
\hline Rice hulls & $12.0(0.42)$ & $26.9(1.5)$ & $9.9(0.5)$ & $37.2(2.5)$ & $36.8(0.36)$ \\
\hline Sorghum stems & $37.8(0.89)$ & $30.9(5.1)$ & $4.4(1.2)$ & $16.4(1.8)$ & $14.5(0.48)$ \\
\hline Wheat straw & $4.2(0.72)$ & $8.2(0.1)$ & $0.7(0.2)$ & $24.1(1.8)$ & $8.1(0.25)$ \\
\hline
\end{tabular}

directly without drying and chopping. Moisture contents of crop residue feedstock are given in Table 1.

Total carbon concentration of the biomass was determined by dry combustion in a Leco C-144 carbon analyzer (Merry and Spouncer, 1988). Total N was determined using a block digester method (Wendt, 1997) and total $P$ by an acid persulfate digestion method (Liao and Marten, 2001). Exchangeable cations (i.e., K, $\mathrm{Ca}$ and $\mathrm{Mg}$ ) were determined by atomic absorption spectrometry using ammonium acetate extraction procedures (Thomas, 1982). Micronutrient (i.e., $\mathrm{Zn}, \mathrm{Fe}, \mathrm{Cu}$ and $\mathrm{Mn}$ ) contents were determined by atomic absorption spectrophotometer extracted by using the DTPA extraction procedure (Jones Jr and Case, 1990). Ash content of biochar was determined by combustion at $900^{\circ} \mathrm{C}$ in the muffle furnace for an hour. SAS GLM procedure and Duncan's multiple range tests were employed to test for statistical significance between and among treatments.

\section{Results and Discussion}

Moisture content of biomass samples ranged from $4.2 \%$ for wheat straw to $37.8 \%$ for sorghum stems (Table 1). Average input amount of biomass sample as a feedstock to fill the pyrolysis reactor (i.e., $0.33 \mathrm{~m}^{3}$ ) ranged from $8.2 \mathrm{~kg}$ for wheat straw to $30.9 \mathrm{~kg}$ for sorghum stems. Average output amount of biochar ranged from $0.7 \mathrm{~kg}$ for wheat straw to $9.9 \mathrm{~kg}$ for rice hull. Ash content of biochar was observed from 16.6\% for sorghum to $37.2 \%$ for rice hulls. Such a high ash content of biochar can be explained by manual operation of pyrolyzer, which has limitation of precise oxygen control in the reactor. Highest biochar yield was about $36.8 \%$ from corn stems and rice hulls, while the lowest

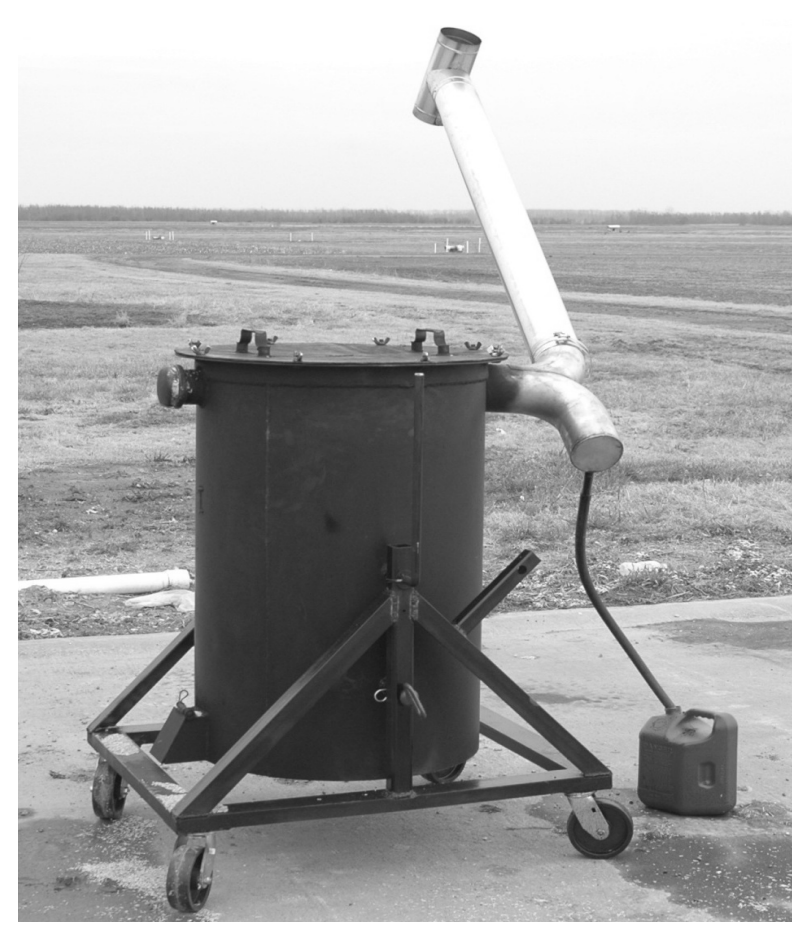

Fig. 1. Field scale biomass pyrolyzer developed by University of Missouri Delta Research Center. Pyrolysis converts crop biomasses in the reactor (i.e., $0.33 \mathrm{~m}^{3}$ ) that is run at $400-500^{\circ} \mathrm{C}$ for 3-4 hours produce each batch of biochar. Note the air intake on the lower left of the reactor and the exhaust chimney above. The container on the right is catching the bio-oil.

was about $8.1 \%$ from wheat straw. Contents of C, N, P, $\mathrm{K}, \mathrm{Ca}, \mathrm{Mg}, \mathrm{Fe}, \mathrm{Zn}, \mathrm{Mn}$, and $\mathrm{Cu}$ in the feedstock and biochar are given in Table 2, Fig. 2 and Fig. 3. Total carbon content was significantly highest in cotton stem biomass samples and lowest in rice hulls. Average carbon content of biomass $\left(445 \mathrm{~g} \mathrm{~kg}^{-1}\right)$ was increased in biochar $\left(597 \mathrm{~g} \mathrm{~kg}^{-1}\right)$ by $34 \%$. The total carbon content of biochar from cotton stems and sorghum stems was increased by $50 \%$ and $40 \%$, respectively, whereas that of rice hulls was increased by only $18 \%$. 
Table 2. Elemental content of crop biomass samples based on dry weight $(n=3)$. Means among feedstock samples or biochar samples followed by the same letter do not differ at the $<0.05$ level.

\begin{tabular}{|c|c|c|c|c|c|c|c|c|c|c|}
\hline Biomass sample & $\mathrm{C}$ & $\mathrm{N}$ & $\mathrm{P}$ & $\mathrm{K}$ & $\mathrm{Ca}$ & $\mathrm{Mg}$ & $\mathrm{Fe}$ & $\mathrm{Zn}$ & $\mathrm{Mn}$ & $\mathrm{Cu}$ \\
\hline & \multicolumn{9}{|c|}{ 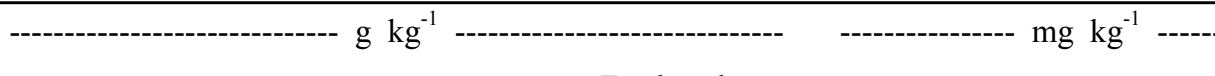 } & $----\cdot$ \\
\hline & \multicolumn{10}{|c|}{ Feedstock } \\
\hline Corn stems & $448_{\mathrm{c}}$ & $10.9 \mathrm{a}$ & $2.63_{\mathrm{a}}$ & $8.42_{b}$ & $3.58 \mathrm{~b}$ & $1.92_{\mathrm{a}}$ & $30.0_{\mathrm{a}}$ & $380_{\mathrm{a}}$ & $101.0_{\mathrm{b}}$ & $6.7 \mathrm{a}$ \\
\hline Cotton stems & $466_{a}$ & $8.4_{b}$ & $1.04_{\mathrm{b}}$ & $7.07 \mathrm{bc}$ & $6.60_{\mathrm{a}}$ & $1.29 \mathrm{~b}$ & $15.6_{b}$ & $146_{b}$ & $25.0_{\mathrm{d}}$ & $5.0_{\mathrm{b}}$ \\
\hline Rice hulls & $409_{d}$ & $5.1_{d}$ & $0.52_{\mathrm{c}}$ & $1.48_{\mathrm{d}}$ & $1.28 \mathrm{e}$ & $0.46_{\mathrm{c}}$ & $16.0_{\mathrm{b}}$ & $69_{\mathrm{c}}$ & $256.3_{\mathrm{a}}$ & $4.3_{b}$ \\
\hline Sorghum stems & $449 \mathrm{c}$ & $6.6_{c}$ & $1.01_{\mathrm{b}}$ & $6.50_{c}$ & $2.28_{\mathrm{d}}$ & $1.61_{\mathrm{ab}}$ & $24.4_{\mathrm{a}}$ & $55_{c}$ & $43.0_{\mathrm{c}}$ & $5.0_{\mathrm{b}}$ \\
\hline Wheat straws & $454_{b}$ & $5.3_{\mathrm{d}}$ & $0.43_{\mathrm{c}}$ & $15.34_{\mathrm{a}}$ & $3.02_{\mathrm{c}}$ & $1.45_{\mathrm{b}}$ & $8.1_{\mathrm{c}}$ & $27 \mathrm{c}$ & $28.0_{\mathrm{d}}$ & $4.6 \mathrm{~b}$ \\
\hline F-value & 200.6 & 102.0 & 67.3 & 93.6 & 167.4 & 25.9 & 18.3 & 43.5 & 1466.4 & 3.9 \\
\hline \multirow[t]{2}{*}{$\operatorname{Pr}>F$} & $<.0001$ & $<.0001$ & $<.0001$ & $<.0001$ & $<.0001$ & $<.0001$ & $<.0001$ & $<.0001$ & $<.0001$ & 0.04 \\
\hline & \multicolumn{10}{|c|}{$\underline{\text { Biochar }}$} \\
\hline Corn stems & $549_{b}$ & $16.2_{\mathrm{a}}$ & $6.56_{\mathrm{a}}$ & $9.31_{\mathrm{c}}$ & $8.70_{\mathrm{c}}$ & $4.04_{c}$ & $89.3_{\mathrm{a}}$ & $1844_{b}$ & $273.6_{b}$ & $9.2_{\mathrm{b}}$ \\
\hline Cotton stems & $697 \mathrm{a}$ & $12.9_{\mathrm{b}}$ & $5.86_{b}$ & $15.38_{\mathrm{b}}$ & $25.89 \mathrm{a}$ & $5.10_{\mathrm{a}}$ & $49.3_{b}$ & $3462_{\mathrm{a}}$ & $141.6_{\mathrm{c}}$ & $16.6_{\mathrm{a}}$ \\
\hline Rice hulls & $481_{b}$ & $6.1_{d}$ & $0.90_{\mathrm{e}}$ & $2.91_{d}$ & $1.97_{\mathrm{d}}$ & $0.72_{\mathrm{d}}$ & $22.8_{\mathrm{c}}$ & $93_{\mathrm{d}}$ & $521.3_{\mathrm{a}}$ & $6.6_{\mathrm{b}}$ \\
\hline Sorghum stems & $627 \mathrm{a}$ & $7.3_{\mathrm{c}}$ & $3.87_{\mathrm{c}}$ & $13.68 \mathrm{~b}$ & $7.41_{c}$ & $4.54_{b}$ & $82.2_{\mathrm{a}}$ & 2899 a & $157.6_{\mathrm{c}}$ & $8.6 \mathrm{~b}$ \\
\hline Wheat straws & $630_{a}$ & $5.8_{\mathrm{d}}$ & $1.86_{\mathrm{d}}$ & $20.29 \mathrm{a}$ & $11.79 \mathrm{~b}$ & $4.73_{\mathrm{ab}}$ & $24.4_{c}$ & $897_{\mathrm{c}}$ & $127.3_{\mathrm{c}}$ & $6.5 \mathrm{~b}$ \\
\hline F-value & 13.8 & 232.4 & 240.6 & 85.3 & 314.4 & 182.7 & 72.8 & 47.6 & 21.6 & 9.2 \\
\hline $\operatorname{Pr}>F$ & 0.004 & $<.0001$ & $<.0001$ & $<.0001$ & $<.0001$ & $<.0001$ & $<.0001$ & $<.0001$ & $<.0001$ & 0.002 \\
\hline
\end{tabular}

Table 3. Estimation of biochar retums for carbon and nutrients from pyrolysis of 1 Mg biomass. Standard deviations are in parentheses $(n=3)$.

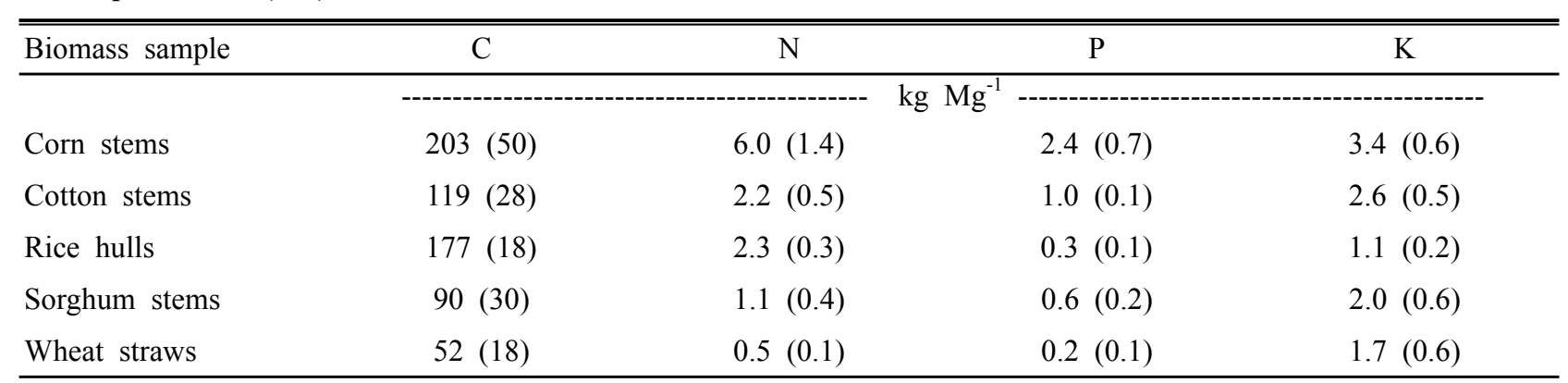

The total $\mathrm{N}$ content differed among biomass samples, being highest in corn stems and cotton stems. Following pyrolysis, biochar from corn stems had $48 \%$ higher total $\mathrm{N}$ content and that from cotton stems had 54\% higher total $\mathrm{N}$ content than the feedstock. Rice hulls had the lowest total $\mathrm{N}$ content in the biomass and the total $\mathrm{N}$ content of the biochar was not significantly higher. Contents of $\mathrm{P}, \mathrm{K}, \mathrm{Ca}$, and $\mathrm{Mg}$ were different among feedstock and biochar samples which generally were consistent with their contents in the biochar formed. Average $\mathrm{P}$ content was $>3$-fold higher in biochar samples than feedstock samples. Significant high $\mathrm{P}$ content was found in biochar samples of cotton stems and wheat straws samples when compared to feedstock samples.

Content of $\mathrm{K}$ differed among feedstocks and the biochar formed from them. Biochar $\mathrm{K}$ from cotton and sorghum stems was double that of their respective feedstock samples. Average $\mathrm{Ca}$ and $\mathrm{Mg}$ content were $>3$-fold higher in biochar samples than in feedstock samples. Micronutrient (i.e., Fe, $\mathrm{Zn}, \mathrm{Mn}$, and $\mathrm{Cu}$ ) contents were significantly different among the biomass samples in feedstock and biochar. But, no significant difference between feedstock and biochar was found in $\mathrm{Zn}, \mathrm{Fe}$, and $\mathrm{Cu}$ content for rice hulls sample. $\mathrm{Zn}, \mathrm{Fe}$, $\mathrm{Mn}$ and $\mathrm{Cu}$ content of biochar samples were $>3$-fold, $>13$-fold, 2.5-fold, and 1.5-fold higher than feedstock samples, respectively. 

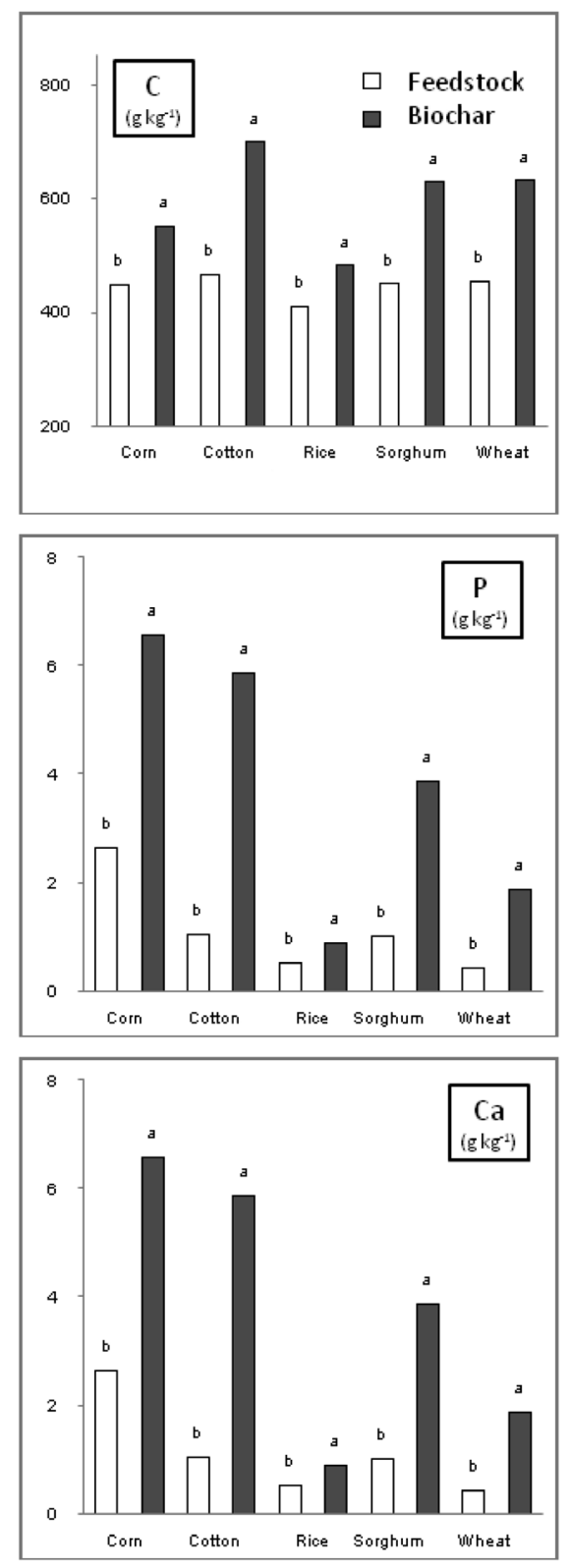
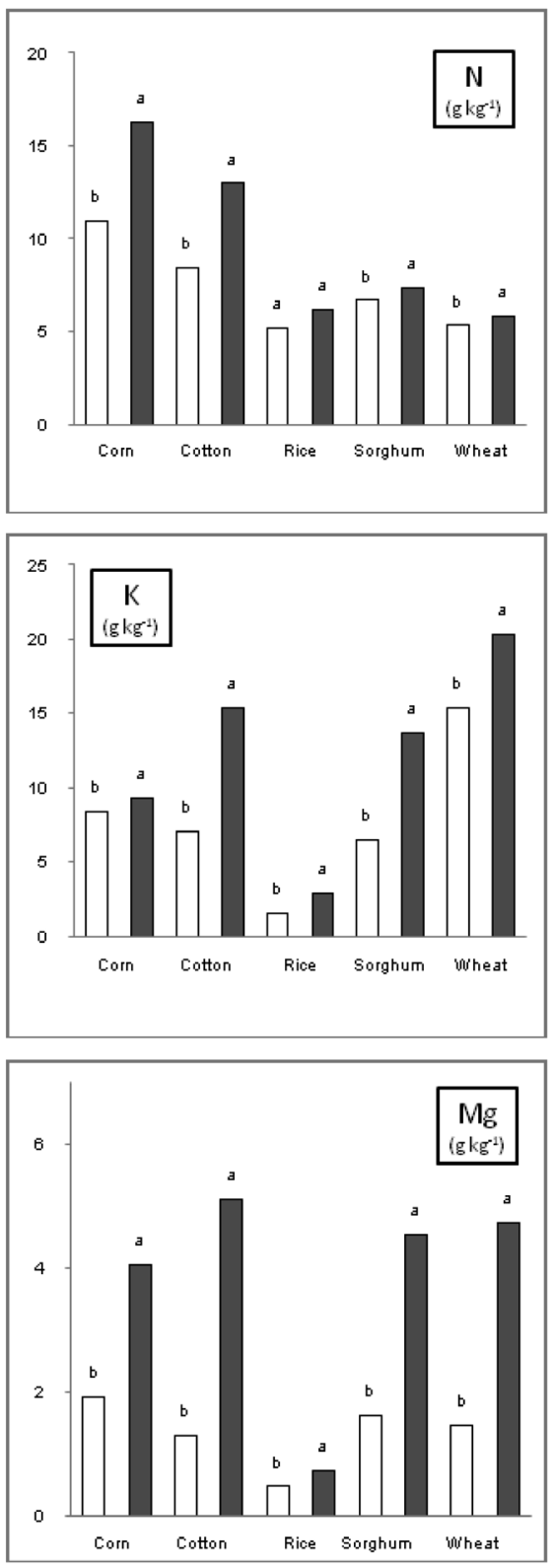

Fig. 2. Comparison of nutrient contents of the crop biomass feedstock and the biochar it produced (n=3). Means within a feedstock with the same letter are not different at $p<0.05$.

Biochar production from corn stems and rice hulls was relatively high in carbon retention (i.e., $203 \mathrm{~kg}$ and $177 \mathrm{~kg}$ from $1 \mathrm{Mg}$ of biomass) while wheat straw was relatively low in carbon retention (i.e., $52 \mathrm{~kg}$ from $1 \mathrm{Mg}$ of biomass) (Table 3). Cotton stems biochar retained the highest amount of $\mathrm{N}$ (i.e., $6.0 \mathrm{~kg}$ ), P (i.e., $2.4 \mathrm{~kg}$ ), and $\mathrm{K}$ (i.e., $3.4 \mathrm{~kg}$ ) while wheat straw biochar retained the lowest amount of $\mathrm{N}$ (i.e., $0.5 \mathrm{~kg}$ ) and P (i.e., $0.2 \mathrm{~kg}$ ). Rice hulls biochar retained the lowest amount of $\mathrm{K}$ (i.e., $1.1 \mathrm{~kg})$.

The biomass feedstock samples differed in dry moisture content (Table 1). Those of corn stems, cotton stems, and sorghum stems decreased in moisture content by $30 \%$ for a week of air drying, but there was no change in moisture content of rice hulls and wheat straw (data not shown). Because rice hull biomass already has a uniform particle size (i.e., $<5 \mathrm{~mm}$ in diameter), the chopping process is not necessary. Therefore, rice hulls biomass was already dried and required the least use of energy to prepare for pyrolysis. Despite a range in moisture contents of biomass samples, the pyrolysis system runs very well under natural outdoor conditions.

Previous research has reported that organic carbon in biochar is very resistant against microbial decomposition and works in the soil much like soil organic matter (DeLuca et al., 2009; Lehmann, 2009). When 

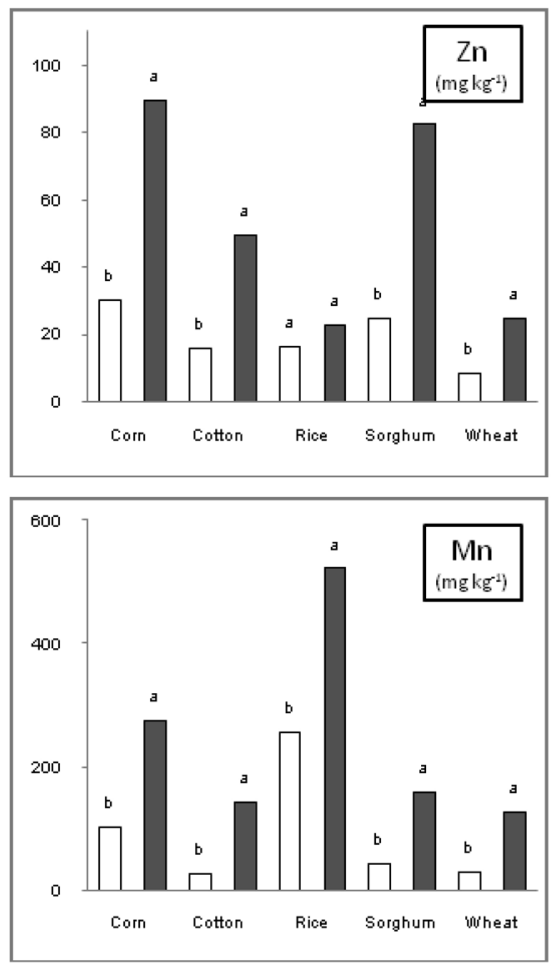
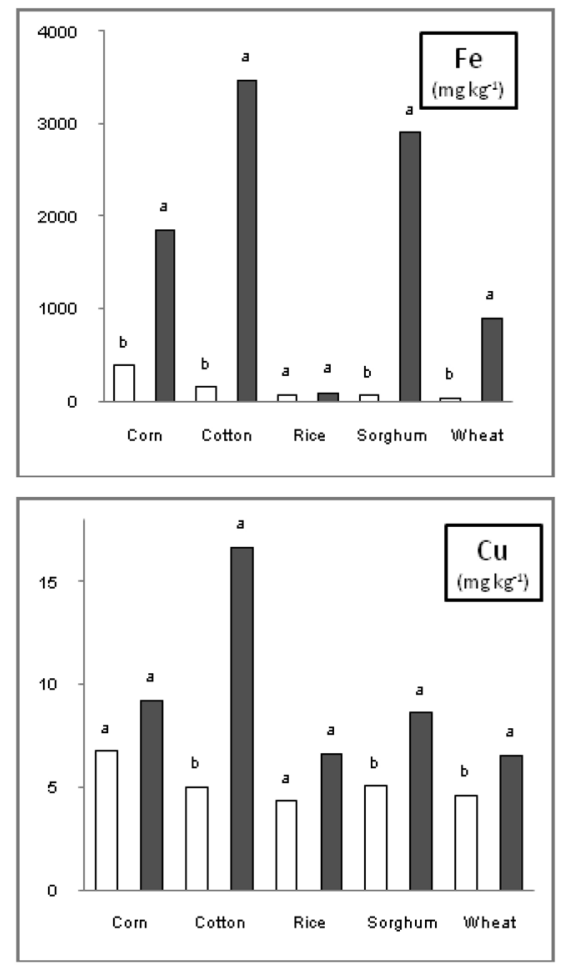

Fig. 3. Comparison of micro-nutrients contents between crop biomass feedstock and the biochar produced (n=3). Means within a feedstock with the same letter are not different at $\mathbf{p}<\mathbf{0 . 0 5}$.

biochar is returned to soil, we expect that on average $13.3 \%$ of the biomass weight could be sequestered in the soil for several decades or centuries. Specifically, biochar from corn stems and rice hulls, respectively, can sequester $20 \%$ and $17.7 \%$ the biomass weight. Lehmann et al. (2006) reported that biochar can sequester up to $50 \%$ of the initial carbon input. However, we found that biochar from corn stems and rice hulls can sequester by $60 \%$ and $49 \%$ of the initial carbon input from the biomass respectively when biochar is incorporated into the soils. This result implies that pyrolysis conversion of biomass to biochar contributes significantly to sequester carbon that can be applied to soils. However, few research data have been reported especially for practical application of pyrolysis and biochar use at the local farm scale. Therefore, these results provide fundamental data for future research on small scale biochar production. Furthermore, agronomic and environmental impacts and conditions for biochar application should be investigated with various biomass sources and crops.

\section{Conclusions}

We developed low-cost on farm biomass pyrolysis system, which can be used to produce biochar at the farm level from locally collected feedstocks. This pyrolysis system is designed for operating without continuous non-feedstock energy use. Bio-oil, a byproduct with economic value, was collected during pyrolysis and is being evaluated. Foremost advantage of this biomass pyrolyzer is ease to adopt this manual system for producing biochar at the local farm. Furthermore, pyrolysis conversion of crop residues can sequester significant amounts of carbon as biochar which has further environmental and production benefits when applied to soils.

\section{Acknowledgements}

This research was supported by USDA-ARS. The authors are grateful for the contributions of G. Tucker and T. Matthews for field data collection and analysis.

\section{Disclaimer}

Mention of trade names or commercial products in this publication is solely for the purpose of providing specific information and does not imply recommendation or endorsement by the University of Missouri. 


\section{References}

Alves A., M. Schwanninger, H. Pereira, and J. Rodrigues. 2006. Analytical pyrolysis as a direct method to determine the lignin content in wood: Part 1: Comparison of pyrolysis lignin with Klason lignin. Journal of Analytical and Applied Pyrolysis 76:209-213.

Baldock, J. and R. Smernik. 2002. Chemical composition and bioavailability of thermally altered Pinus resinosa (Red pine) wood. Organic Geochemistry 33:1093-1109.

Cunha, T., B. Madari, L. Canellas, L. Ribeiro, V. Benites, and G. Santos. 2009. Soil organic matter and fertility of anthropogenic dark earths (Terra Preta de Índio) in the Brazilian Amazon basin. Revista Brasileira de Ciência do Solo 33:85-93.

DeLuca, T., M. MacKenzie, and M. Gundale. 2009. Biochar Effects on Soil Nutrient Transformations. In: Lehmann J and Joseph S. (eds.) Biochar for environmental management: science and technology:pp., 251-285. Eatthscan Publishing: London, Sterlin, VA.

Demirba, A. 2001. Biomass resource facilities and biomass conversion processing for fuels and chemicals. Energy Conversion and Management 42:1357-1378.

Glaser, B. 2007. Prehistorically modified soils of central Amazonia: a model for sustainable agriculture in the twenty-first century. Philosophical Transactions of the Royal Society B: Biological Sciences 362:187.

Glaser, B., E. Balashov, L. Haumaier, G. Guggenberger, and W. Zech. 2000. Black carbon in density fractions of anthropogenic soils of the Brazilian Amazon region. Organic Geochemistry 31:669-678.

Goldstein, I. and C.R. Company. 1981. Organic chemicals from biomass. CRC press Boca Raton, FL.

Hansen J., M. Sato, P. Kharecha, D. Beerling, R. Berner, V. Masson-Delmotte, M. Pagani, M. Raymo, D. Royer, and J. Zachos 2008. Target atmospheric $\mathrm{CO}_{2}$ : Where should humanity aim? Open Atmospheric Science Journal 2:217-231.

Howard, J. 1981. Fundamentals of coal pyrolysis and hydropyrolysis. Chemistry of Coal Utilization 2:665-784.

Jones Jr., J. and V. Case. 1990. Sampling, handling, and analyzing plant tissue samples. Soil Testing and Plant Analysis 3:389-428.

Lal, R. 2004. Soil carbon sequestration impacts on global climate change and food security. Science 304:1623.

Lehmann, J. 2007a. Bio-energy in the black. Frontiers in Ecology and the Environment 5:381-387.

Lehmann, J. 2007b. A handful of carbon. Nature 447:143-144.

Lehmann, J. 2009. Biological carbon sequestration must and can be a win-win approach. Climatic Change 97:459-463.

Lehmann, J., J. Gaunt, and M. Rondon. 2006. Bio-char sequestration in terrestrial ecosystems-a review. Mitigation and Adaptation Strategies for Global Change 11:395-419.
Liang, P., Z. Wang, and J. Bi. 2007. Process characteristics investigation of simulated circulating fluidized bed combustion combined with coal pyrolysis. Fuel Processing Technology 88:23-28.

Liao, N. and S. Marten. 2001. Determination of total phosphorus by flow injection analysis colorimetry (acid persulfate digestion method). QuikChem ${ }^{\circledR}$ Method:10-115.

Malhi, S., R. Lemke, Z. Wang, and B. Chhabra. 2006. Tillage, nitrogen and crop residue effects on crop yield, nutrient uptake, soil quality, and greenhouse gas emissions. Soil and Tillage Research 90:171-183.

McHenry, M. 2009. Agricultural bio-char production, renewable energy generation and farm carbon sequestration in Western Australia: Certainty, uncertainty and risk. Agriculture, Ecosystems \& Environment 129:1-7.

McKendry, P. 2002. Energy production from biomass (part 1): overview of biomass. Bioresource Technology 83:37-46.

Merry, R. and L. Spouncer. 1988. The measurement of carbon in soils using a microprocessor-controlled resistance furnace. Communications in Soil Science and Plant Analysis 19: 707-720.

Mohan, D., C. Pittman Jr., and P. Steele. 2006. Pyrolysis of wood/biomass for bio-oil: a critical review. Energy Fuels 20:848-889.

Oasmaa, A., D. Elliott, and S. Müller. 2009. Quality control in fast pyrolysis bio-oil production and use. Environmental Progress \& Sustainable Energy 28:404-409.

Soil Survey Staff. 1997. Keys to soil taxonomy. Pocahontas Press, Blacksburg, VA.

Teasdale, J., A. Abdul-Baki, and Y. Bong Park. 2008. Sweet corn production and efficiency of nitrogen use in high cover crop residue. Agronomy for Sustainable Development 28: 559-565.

Teng, H., H. Lin, and J. Ho. 1997. Thermogravimetric analysis on global mass loss kinetics of rice hull pyrolysis. Industrial \& Engineering Chemistry Research 36:3974-3977.

Thomas, G. 1982. Exchangeable cations. In: A.L Page (ed.) Methods of Soil Analysis, PArt 2 Chemical and Microbiological Properties, $2^{\text {nd }}$ edition. Agronomy 9:159-165.

Van Zwieten, L., S. Kimber, S. Morris, K. Chan, A. Downie, J. Rust, S. Joseph, and A. Cowie. 2010. Effects of biochar from slow pyrolysis of papermill waste on agronomic performance and soil fertility. Plant and Soil 327:235-246.

Wendt, K. 1997. Determination of total Kjeldahl nitrogen by flow injection analysis colorimetry (block digestor method). QuikChem Method:10-107.

Zhang, X., S. Kondragunta, C. Schmidt, and F. Kogan. 2008. Near real time monitoring of biomass burning particulate emissions (PM2. 5) across contiguous United States using multiple satellite instruments. Atmospheric Environment 42: 6959-6972. 